\title{
Fighting against Aridity: Diponegoro University's Environmental Management towards a Green Campus
}

\author{
Tri Handayani*, Yety Rochwulaningsih, Singgih Tri Sulistiyono \\ Faculty of Humanities, Diponegoro University, Semarang, Indonesia
}

\begin{abstract}
Diponegoro University (Undip) is one of the state universities (PTN) in Indonesia which has experienced three changes in its financial management status, ranging from PTN Working Unit (1960) and PTN Public Service Agency (2008) to PTN Legal Entity. The status of PTN Legal Entity was legalized in 2015 and operated in 2017. The implementation of three pillars of higher education and institutional development have been confronted with funding factors and commitment from all components of higher education. The need of stakeholders for university graduates continuing to develop their competencies made this university moved its campus center to Tembalang. This move had a variety of environmental impacts both inside and outside the campus. Various efforts continued to be made by the university to overcome the environmental impacts. Undip's participation in the green campus ranking based on GreenMetric World University Ranking since 2012 was an effort so that the university could find out the consistency of sustainable environmental management to maintain a sustainable environment for the benefits of the next generation. This paper focuses on the analysis of environmental management developed by Undip to realize a 'green campus'. The conclusion of this research underlines that Undip needed to optimize all efforts.
\end{abstract}

\section{Introduction}

Diponegoro University (Undip) was established as state university (PTN) on December 3, 1960 based on the Decree of the Minister of Education, Teaching and Culture of the Republic of Indonesia Number 101247/Law[1]. This state university (PTN) was founded due to the needs of the local communities so that they could continue their education to higher education. Historically, the establishment to the growth and development of the PTN was closely related to the local government and residents of Central Java[2]. The PTN was growing and developing as PTN in general. PTN was difficult to progress and develop since the financial management was fully managed by the government. In that period, Undip continued to grow according to the needs of stakeholders. The need for experts from Undip graduates made this PTN had to expand its campus in Tembalang area of Semarang.

\footnotetext{
* Corresponding author: tri.handayani.undip@gmail.com
} 
The campus operations were gradually carried out at Tembalang campus starting in 1997[3]. Undip as a dynamic PTN was difficult to progress without sufficient funds to support the activities of three pillars of higher education and funds for institutional development. Therefore, Undip Management strived to make the financial management status more flexible according to the applicable rules. The struggle carried out in 2007 was successful with the issuance of the Decree of the Minister of Finance Number 259/KMK.05/2008 on the Establishment of Diponegoro University as a Government Institution Implementing Financial Management of Public Service Agency[4]. Undip with the status of state university (PTN) Public Service Agency issued a number of policies to obtain funds for the implementation of three pillars of higher education and institutional development.

The autonomy era entered into higher education in Indonesia in 1999. Undip with limited funds and resources gradually headed towards autonomous state universities. The status was based on the Government Regulation of the Republic of Indonesia Number 81 of 2014 on the Establishment of Diponegoro University as PTN Legal Entity and the Government Regulation of the Republic of Indonesia Number 52 of 2015 on Diponegoro University Statute. Undip as PTN Legal Entity was launched in 2017[5].

Based on Undip's history, it can be seen that this PTN has proven its toughness since its establishment. The strength of the funds is undeniably a factor that also determines the sustainability of the university, including the sustainability of resources and the campus environment. Each study program has a strategy to overcome the lack of funding from the University and the Faculty. For example, the Department of History of the Faculty of Literature (now the Faculty of Cultural Sciences) addressed the need for afforestation of the campus in Building B of this faculty through lecturer contributions in that department. This condition occurred in 2004 because the Departments of History and Diploma III Archives were the Department and Diploma III Study Program from the faculty that first moved to Tembalang campus [6]. The relocation of Undip campus from Pleburan to Tembalang also had negative impacts on the campus environment. These impacts included floods, garbage buildup, air pollution, increased population density, not environmentally friendly transportation, congestion, and others[7-9]. These conditions were challenges for all campus components to become a campus able to maintain the sustainability of its environment. In this connection, this paper would examine how Undip developed sustainable environmental management so that it was able to preserve and develop the campus environment into a green campus.

\section{Method}

This was qualitative research. The data were collected through observations and secondary sources. The observations were made on Undip environment in Tembalang campus, Semarang. In addition, the data were also collected through literature studies, including research journals related to Undip campus environment in Tembalang, published books, and electronic books. Moreover, interview was also conducted with Undip's Vice Chancellor regarding the transformation status of Undip from PTN Working Unit to PTN Legal Entity. The data on the efforts made by Undip to preserve the environmental sustainability were obtained from online campus news and online newspapers [10]. After the data were collected, critics of various sources were carried out to determine the suitability of the data with the research. Then reconstruction was carried out to obtain an article entitled "Fighting against Aridity: Diponegoro University's Environmental Management towards a Green Campus". 


\section{Results and Discussion}

\subsection{Green Campus Concept}

Green campus is an extremely popular concept in the college environment in the United States in the mid-1990s. Peggy F. Barlett and Geoffrey W. Chase gathered various community experiences from various campuses in the United States about their efforts to maintain the campus environmental sustainability. Peggy and Geoffrey subsequently edited the experiences and published them in 2004 in a book entitled Sustainability on Campus: Stories and Strategies for Change[11].

There were several aspects that they discussed related to the issue of campus environmental sustainability. There were five main issues contained in the book entitled Sustainability on Campus: Stories and Strategies for Change written by campus communities from various universities in the United States. Of the five main sub-issues and sub-issues, it was known that the green campus did not only mean campus afforestation activities. Green campus was a movement to maintain environmental sustainability, initiated by the campus communities.

The first issue discussed the basis of creating sustainable universities. We would know through this issue that to implement environmental sustainability, a Green Task Force was needed. It was called a task force because it was a group of people consisting of about fifty people. Their jobs were to monitor the waste produced as a result of activities in the campus environment, to manage waste systematically, to calculate the rate of waste growth, to conduct awareness campaigns on environmental awareness, to conduct an audit of every energy used, including the use of electricity, water, office stationery. Awareness that in order to make changes we did not just wait was included in this issue. We had to do it so changes occurred. Anyone could lead to changes in community culture to care for the environment.

The first issue part contained the elements of communication and respect as keywords for the success of the sustainability program. Good communication accompanied by polite attitude would bring people who initially did not care for the environment turned into those who did so[12]. This opinion was in line with public policy theory by George C. Edward III in his book entitled Implementing Policy stating that there were four elements for successful policy implementation. First was communication, second was bureaucratic structure, third was resources, and fourth was disposition[13].

The second issue was about curriculum redesign. Referring to the presentation of the study, it was known that curriculum redesign has been applied to faculties at Northern Arizona University since 1995. The curriculum design was designed across disciplines such as music, geology, nursing, and others. Curriculum design integrated environmental sustainability issues in the curriculum. Oakland Community College also implemented changes to the curriculum, so they implemented the college graduates as environmentbased graduates. The third issue discussed learning.

The fourth issue was about the involvement of communities and students in implementing campus sustainability programs. An example of the applied concept was involving students in providing learning experiences to children about nature. The fifth issue was an issue emphasizing commitment building on environmental sustainability in all systems. In principle, the movement to maintain environmental sustainability was carried out so that future generations would not run out of biological resources for their survival.

The green campus was actually an effort to maintain the campus sustainability so that the existing campus environment resources could continue to be sustainable. This concept was started from campus since the campus communities were potential communities to implement the concept. Rahayu Effendi, Hana Salsabila, Abdul Malik[14] provided a 
number of alternative understandings about the sustainable environment. The conclusion they took regarding the understanding of sustainable environment was "as a condition of balance, resilience, and connection that enabled humans to meet their needs without exceeding the capacity of the supporting ecosystem and be able to regenerate to continue to be able to meet the needs of the future." Further details of the sustainable environment are as follows[15]: "1. Social and economic environment: a. Producing what is needed for future generations to maintain sustainability; $b$. Designing products that play a role in economic sustainability. 2. Living environment: a. Maintaining biodiversity of natural resources; $b$. Being responsible for the use of sustainable resources with efficient energy use; c. Maintaining the harvest rate by not exceeding the rate of regeneration; $c$. Developing non-renewable resources proportional to the reduction in those resources; $d$. Applying recycling or material reuse; e. Reducing waste emissions as impact on the environment"

Referring to the understanding presented by Peggy F. Barlett and Geoffrey W. Chase as the editors and presentation of Rahayu Effendi, Hana Salsabila, Abdul Malik, there was a similarity in which both of them maintained environmental sustainability to meet the needs of the lives of the next generation.

\subsection{UI GreenMetric World University Ranking}

UI GreenMetric is a reference for Undip in an effort to maintain the sustainability of Undip campus environment[16]. UI GreenMetric is a moral movement initiated by University of Indonesia in the form of a university ranking at the national and international levels related to environmental issues[17]. The Rector of University of Indonesia states that there are things that can be learned by participating in this event, namely[18]:

a. Participants can make their obtained achievements as a mirror evaluation of policies related to environmental sustainability on campus and their implementation

b. Participants can compare their achievements that year with fellow participants

c. Participants can share experiences with fellow participants through UI GreenMetric network regarding sustainability policies in the campus environment

d. Participants can make ranking achievements as media of cooperation among universities to make the world a better place

The methodologies used in UI GreenMetric are[19]:

a. The philosophy: environment, economics, equity

b. The criteria: the collection of basic information of the size of the university and its zoning profile, whether urban, suburban, or rural. The degree of green space, electricity consumption, transportation, water usage, waste management, setting \& infrastructure, energy \& climate change, education and research, how the university is responding to or dealing with the issues of sustainability through policies, actions, and communication.

c. Scoring: scoring for each item is numeric

d. The weighting of criteria: Each criterion is categorized in the general information class and when we process the results, the raw score is weighed to provide the final calculation

e. Refining and improving the research instrument: we review the criteria and weights continuously to reflect input from the participants and the latest developments in the field.

f. Data collection: data are collected from universities/participants between May and October

g. Announcement of results: December

The assessment indicators in GreenMetric UI are[20]: 
a. Setting and Infrastructure (SI) maximum value of $15 \%$. This component is to assess the existence of space for afforestation and how the campus protects the environment and develops energy. The assessed indicators in this component include:

"1. The ratio of open space area towards total area

2. Area on campus covered in forest

3. Area on campus covered in planted vegetation

4. Area on campus for water absorbance

5. The total open space area divided by total campus population

6. University budget for sustainable effort"

b. Energy and Climate Change (EC) maximum value of $21 \%$. This component has the highest component weighting value compared to other value components. It is known that this component contains energy use and climate change issues. The assessed indicators include:

"1. Energy efficient appliances usage are replacing conventional appliances

2. Smart Building implementation

3. Number of renewable energy sources in campus

4. The total electricity usage divided by total campus population (kWh per person)

5. The ratio of renewable energy produced towards energy usage

6. Elements of green building implementation as reflected in all construction and renovation policy

7. Greenhouse gas emission reductions program

8. The ratio of total carbon footprint divided campus population"

c. Waste (WS) maximum value of $18 \%$

This component assesses some programs and waste treatments, i.e. recycling program, toxic waste recycling, organic waste treatment, inorganic waste treatment, sewerage disposal, policy to reduce the use of paper and plastic in campus. The assessed indicators include:

"1. Recycling program for university waste

2. Program to reduce the use of paper and plastic in campus

3. Organic waste treatment

4. Inorganic waste treatment

5. Toxic waste handled

6. Sewerage disposal"

d. Water (WR) maximum value of $10 \%$

This component assesses the use of water on campus. This indicator shows the efforts of the ranking developer so that the campus communities use water wisely. Moreover, they are also expected to improve conservation programs and protect habitats. The assessed indicators include:

"1. Water conservation program implementation

2. Water recycling program implementation

3. The use of water efficient appliances (water tap, toilet flush, etc.)

4. Treated water consumed"

e. Transportation (TR) maximum value of $18 \%$

This component evaluates the mode of transportation used by the campus communities in the campus environment. The aim is to minimize pollution generated by passing vehicles in the campus environment. The assessed indicators include:

“1. The Ratio of total vehicles (cars and motorcycles) divided by total campus population 
2. Shuttle service

3. Zero Emission Vehicles (ZEV) policy on campus

4. The ratio of Zero Emission Vehicles (ZEV) divided by total campus population

5. Ratio of parking area to total campus area

6. Transportation program designed to limit or decrease the parking area on campus for the last 3 years

7. Number of transportation initiatives to decrease private vehicles on campus

8. Pedestrian path policy on campus"

f. Education and Research (ED) maximum value of $18 \%$

This component is based on the consideration that universities have the potential to create awareness of the new generation with sustainability issues. The assessed indicators include:

" 1 . The ratio of sustainability courses towards total courses/subjects

2. The ratio of sustainability research funding towards total research funding

3. Number of scholarly publications on environment and sustainability published

4. Number of scholarly events related to environment and sustainability

5. Number of student organizations related to environment and sustainability

6. Existence of a university-run sustainability website

7. Existence of published sustainability report"

Based on the six components of UI GreenMetric WUR assessment, it is overall known to accommodate a variety of sustainability issues discussed by the campus communities in the United States in the 1990s. The issue that does not appear explicitly in UI GreenMetric WUR is the curriculum about the environment applied to all study programs.

\subsection{Sustainability Management at Diponegoro University}

In the previous presentation, various environmental impacts that occurred after Undip central campus moved to Tembalang were depicted. Various research has been conducted. From the results of research related to the issue about the sustainability of Undip campus environment through the website, it was known that the background of the researchers were students and lecturers. They came from Undip and outside Undip, including Gadjah Mada University and Sugiyapranata Catholic University. All Undip components had attempted to overcome various problems while trying various actions at the same time. The following presentation was a variety of research results and documents that represented the efforts Undip had made towards the green campus.

Suardi explained that the implementation of sustainable development was optimal, but it is a balanced development between natural resources and humans [21]. The results of the research carried out revealed that Undip had made an effort to make the living environment on campus run in harmony with its environment.

Irma Dewi Hapsari, Nugroho Sumarjiyanto BM, Evi Yulia Purwanti used UI GreenMetric WUR reference to analyze the implementation of green campus in Undip environment. According to them, the program has been implemented well, but has not been thoroughly integrated. Hence, Undip has not achieved the title as a sustainable campus. They suggested that Undip achieved the predicate with Analytical Hierarchy Process (AHP) analysis tool, namely:

“(1) Applying campus environment management sustainability budget,

(2) Applying green building concept,

(3) Implement recycling program for university waste,

(4) Implement water conservation program,

(5) Providing campus bus facilities for staff and students, as well as

(6) Promoting organization" 
It was subsequently mentioned that special budget planning was needed for the green campus program so that the program truly provided positive benefits for the environment, economy, and social [22].

Edi Purwanto and Bambang Setioko reviewed and analyzed the green open space layout at Undip. It was one of the indicators of green campus concept. Their results unveil that [23]:

“(1)Tembalang Campus of Diponegoro University has fulfilled several aspects of planning and design principles.

2) Functionally, open spaces of Diponegoro University have been functioning well, such as easy accessibility, well-maintained open space, able to accommodate various activities, and able to provide a balance within Tembalang Campus of Diponegoro University area.

(3) Several open spaces at Diponegoro University, especially active open spaces such as our home garden and deer park were not well maintained so they were not widely used for activities.

(4) In physical and non-physical aspects, the open spaces of Diponegoro University have been well designed, such as good arrangement of trees and plants, facilities such as lighting and drainage systems that have been built properly, and most of the campus area that has been kept clean. However, there were still shortcomings, namely the uneven arrangement of plants and boulevard throughout the area and the gutters filled with leaf litter.

(5) On the environmental aspect, Tembalang Campus of Diponegoro University area had open spaces balanced with the building space.

(6) Tembalang Campus of Diponegoro University also had sufficient recharge areas despite the uneven management and structuring system."

About Afforestation. Some results of the research on efforts to maintain the sustainability of Undip campus unveiled that it still needed optimal efforts so that Undip as a green campus could be truly realized. The efforts to maintain the sustainability of Undip campus environment could be seen from various activities that had been carried out since the early 2000s. The afforestation movement initiated by Undip headquarters began in 2004 by involving Corporate Social Responsibility [24]. The Afforestation Movement was planned at Undip in 2011 by the Rector then led by Prof. Sudharto P. Hadi[25]. The efforts to sustain the campus environment had been instilled in the students since they became new students. The purpose of this policy is to take responsibility for maintaining a beautiful and comfortable campus environment for learning. The procedure is to give them the task of growing green plants. It is expected that the plants will grow big when they graduate as Bachelor[26-28].

About Reservoir. Undip through a grant from the Ministry of Public Works of Directorate General of Water Resources in 2013 built an education reservoir. This reservoir can be used to maintain the balance of ecosystems and environment, flood control in the area around Undip Tembalang campus, as well as educational media for students from the Faculty of Civil Engineering, Chemistry, Environment, Fisheries and Marine, Magister Degree of Dam. Other benefits of this dam are as power plant and recreational facilities[29, 30].

About Drinking Water and Transportation. The research as an effort to get drinking water for Undip environment has been carried out by M. Arief Budihardjo, Wiharyanto Oktiawan, Bayu Sapto Ajie[31] According to them, this effort was highly possible with a strong commitment from various parties in Undip environment. Meanwhile, from the aspect of transportation, it has been reviewed by Nasruddin and Anita Sari R[32]. Their results in 2014 illustrated that 62 percent of students chose to use motorcycle transportation, while 
the remaining 38 percent used public transportation. Various variables including the absence of a driving license or motorized vehicle caused some students to choose to take public transportation. They suggested that the local government immediately conducts comfortable and safe mass vehicles that can quickly arrive at their destination. At this time, Semarang Government has operated mass public transportation called Feeder. The transportation has now been extended to Semarang State University (Unnes) campu [33].

About Campus Forest and Campus Waste. Diponegoro University in cooperation with Pertamina realized the existence of Campus Forest. It is located on the edge of Undip Tembalang campus. The area of Undip Tembalang campus is around 180 hectares. 70 percent of the area is used as Green Open Space (RTH) area. This was a manifestation of Undip's concern for the preservation of nature and environment[34]. Another concern undertaken by Undip was related to waste management generated from the campus environment. Undip, supported by the Ministry of Environment, has been working on the construction of an integrated waste treatment facility (TPST) since 2013. The place is used to manage waste which is a burden on landfills (TPA). It is known that the plan has been realized and operated[35, 36].

Kurniawan Akbar, Yanuar Luqman, Djoko Setiabudi argued that "green university policy is a combination of three elements namely green building, green place, and green behavior applied to the academic community" [39]. All three could be done if conducted through the right strategic communication strategy. With this strategy, the policy could be implemented optimally. This strategy was in line with public policy theory by George C. Edward III[40].

\subsection{Diponegoro University's Performance in UI GreenMetric WUR}

Green campus was an extremely popular concept in the college environment in the United States in the mid-1990s. Their seriousness towards the environmental sustainability was evidenced by at least six universities from the United States in the top ten UI GreenMetric from 2010 to 2019 .

University of Indonesia has initiated awards to universities around the world that have criteria as a green campus under the name UI GreenMetric World University Ranking (WUR). The ranking assessment is based on the commitment and efforts made by universities in afforestation and environmental sustainability. The rating assessment has been started since 2010 involving 95 universities from domestic and abroad. Diponegoro University is one of the participants in the event since the 2012 assessment.

Table 1. Diponegoro University's Achievements in UI GreenMetric WUR Event in 2010 - 2019

\begin{tabular}{llllll}
\hline \multirow{2}{*}{$\begin{array}{c}\text { Year of } \\
\text { Implementation }\end{array}$} & \multicolumn{2}{c}{ Ranking } & \multicolumn{2}{c}{ Total Participants } & \multicolumn{1}{c}{$\begin{array}{c}\text { Total } \\
\text { Score }\end{array}$} \\
\cline { 2 - 5 } 2019 & National & International & National & International & \\
\cline { 2 - 5 } 2018 & 4 & 50 & 71 & 780 & 7,600 \\
2017 & 3 & 78 & 66 & 719 & 7,025 \\
2016 & 6 & 103 & 56 & 619 & 5,643 \\
2015 & 4 & 69 & 42 & 516 & 5,995 \\
2014 & 3 & 45 & 27 & 407 & 5,989 \\
2013 & 5 & 91 & 29 & 361 & 6,172 \\
2012 & 3 & 47 & 25 & 301 & $6,171.63$ \\
2011 & 11 & 166 & 25 & 215 & $4,072.02$ \\
2010 & - & - & 24 & 178 & - \\
\hline
\end{tabular}


Table 1 and Table 2 depicted Undip's achievements as one of the universities in Indonesia concerned with environmental sustainability from 2012 to 2019 . Based on the table's views, it was known that Undip's ranking nationally seemed stable. This achievement was obtained because this university was committed to the efforts to maintain the campus environmental sustainability[37]. The campus environmental sustainability was set in Diponegoro University's Strategic Plan 2015 - 2019[38]. Nevertheless, internationally, Undip's position compared to the increase in numbers of all participants internationally showed a decrease. These achievements indicated that Undip still needed to optimize the commitment of all components in realizing a green campus.

Table 2. Achievements of UI Green Metric Assessment Based on Green Metric World University Rankings (WUR) for Diponegoro University in 2010 - 2019

\begin{tabular}{|c|c|c|c|c|c|c|c|c|c|}
\hline Year & $\begin{array}{l}\text { National } \\
\text { Ranking }\end{array}$ & $\begin{array}{l}\text { International } \\
\text { Ranking }\end{array}$ & $\begin{array}{l}\text { Total } \\
\text { Score }\end{array}$ & $\begin{array}{l}\text { Setting \& } \\
\text { Infrastructure }\end{array}$ & $\begin{array}{l}\text { Energy } \\
\& \\
\text { Climate } \\
\text { Change }\end{array}$ & Waste & Water & Transportation & Education \\
\hline 2019 & 4 & 50 & 7.600 & 750 & 1.575 & 1.350 & 950 & 1.225 & 1.650 \\
\hline 2018 & 3 & 78 & 7.025 & 1.125 & 1.275 & 1.200 & 575 & 1.250 & 1.600 \\
\hline 2017 & 6 & 103 & 5.643 & 773 & 1.132 & 1.101 & 545 & 1.062 & 1.030 \\
\hline 2016 & 4 & 69 & 5.995 & 910 & 1.072 & 1.200 & 545 & 863 & 1.405 \\
\hline 2015 & 3 & 45 & 5.989 & 961 & 1.054 & 1.350 & 620 & 678 & 1.326 \\
\hline 2014 & 5 & 91 & 6.172 & 621 & 1.420 & 1.500 & 525 & 1.375 & 731 \\
\hline 2013 & 3 & 47 & $6.171,63$ & - & - & - & - & - & - \\
\hline 2012 & 11 & 166 & $5.730,63$ & - & - & - & - & - & - \\
\hline 2011 & - & - & - & - & - & - & - & - & - \\
\hline 2010 & - & - & - & - & - & - & - & - & - \\
\hline \multicolumn{10}{|c|}{ Assessment Components } \\
\hline
\end{tabular}

\section{Conclusion}

Based on the previous description, it could be concluded that Diponegoro University as an autonomous state university had no light responsibilities in maintaining the campus sustainability. As a state university, this university must be active and innovative in order to obtain funding sources for the university's survival, including the environmental sustainability. The achievements as a green campus still need to be improved optimally by continuously evaluating the results of the ranking through UI GreenMetric WUR.

\section{Acknowledgements}

In this occassion, the writer would like to say thanks to :

1. DIRSIMLITABMAS for its support and DPRM for doctoral dissertation research funding within two years (2020-2021). This manuscript is a part of doctoral dissertation research funding.

2. Prof. Dr. Yety Rochwulaningsih, M.Si. as disertation promotor and for her support in reaching for this doctoral funding.

3. Prof. Dr. Singgih Tri Sulistiyono, M.Hum. as disertation co-promotor

\section{References}

1. Hamid Abdullah, Dari Universitas Semarang ke Universitas Diponegoro (1984)

2. A.M. Djuliati Suroyo (et.all), Universitas Diponegoro, 1957 - 2012 Pergulatan Menuju Universitas Kelas Dunia (2012) 
3. Dunia Perpustakaan Grup Indonesia, Profil Perpustakaan Universitas Diponegoro. https://www.duniaperpustakaan.com/2016/06/profil-perpustakaanuniversitas_7.html (without year)

4. Interview with Prof.Dr. Muhammad Nur, DEA date May 29, 2020

5. Kemenristekdikti, Kemenristekdikti, Tahun 2017 Undip Resmi Menjadi PTN BH, https://ristekdikti.go.id/kabar/undip-resmi-menjadi-ptn-bh/ Accessed July 19, 2019

6. lpmmanunggal.blogspot.com. "Penghijauan Dalam Lembaran Sejarah". http://lpmmanunggal.blogspot.com/2008/04/sorotan-utama.html Accessed June 16,2020

7. Yonathan Prasetyo dan Paulus Hariyono, "Dampak Spasial Kehadiran Kampus Universitas Diponegoro 01 Kawasan Tembalang Semarang (The Spatial Impact of the College Attendance at Diponegoro University Area of Tembalang Semarang)”, J. Tesa Arsitektu, XII No.1 Juni 2014

8. Budi Prasetyo Samadikun, Sudibyakto, Bakti Setiawan, Rijanta, "Dampak Perkembangan Kawasan Pendidikan di Tembalang Semarang Jawa Tengah (The Impact Development of Education Area in Tembalang Semarang Jawa Tengah)", J. Manusia dan Lingkungan, 21, no.3, November 2014

9. Kampusundip.com, Proyek Sirojudin Tembalang Penyedotan Air Sungai, http://www.kampusundip.com/2017/01/proyek-sirojudin-tembalang-penyedotanair-sungai.html Accessed June 16, 2020

10. John W. Creswell (Translated by Achmad Fawaid dan Rianayati Kusmini Pancasari), Research Design: Pendekatan Metode Kualitatif, Kuantitatif, dan Campuran (2017)

11. Peggy F. Barlett and Geoffrey W. Chase (editor), Sustainability on Campus: Stories and Strategies for Change (2004)

12. Peggy F. Barlett and Geoffrey W. Chase (editor), Sustainability on Campus: Stories and Strategies for Change (2004)

13. George C. Edward III, Implementing Public Policy (1980)

14. Rahayu Effendi, Hana Salsabila, Abdul Malik, "Pemahaman Tentang Lingkungan Berkelanjutan", J. Modul Volume 18 No.2, ossues periode 2018

15. Rahayu Effendi, Hana Salsabila, Abdul Malik, "Pemahaman Tentang Lingkungan Berkelanjutan", J. Modul Volume 18 No.2, ossues periode 2018

16. Ambariyanto, "Kebijakan Undip: Mengelola Lingkungan Kampus di Masa Pandemi Covid-19."

17. http://greenmetric.ui.ac.id/what-is-greenmetric/ Accessed June 13, 2020

18. http://greenmetric.ui.ac.id/letter-from-rector/ Accessed June 13, 2020

19. http://greenmetric.ui.ac.id/methodology-new/ Accessed June 13, 2020

20. http://greenmetric.ui.ac.id/criteria-indicator/ Accessed June 13, 2020

21. Suardi, Problematika Penerapan Prinsip Sustainable Development Dalam Pengelolaan Lingkungan Hidup dan Implikasinya Terhadap Pemenuhan HAM, J. Fiat Justisia J. Ilmu Hukum 8, no. 4, Oktober-Desember 2014

22. Irma Dewi Hapsari, Nugroho Sumarjiyanto BM, Evi Yulia Purwanti, Perencanaan Dan Penganggaran Green Campus Universitas Diponegoro, J. Teknik 35, no.1, 2014

23. Edi Purwanto dan Bambang Setioko, "Kajian Tata Ruang Terbuka Hijau Terhadap Konsep Kampus Hijau di Kampus Universitas Diponegoro”, J. Modul 17, no.2, issues period 2017

24. PT. Taspen (Persero). "Penghijauan di Kampus Undip Semarang". http://www.bumn.go.id/taspen/berita/90, 2007. Accessed June 16, 2020

25. FT Undip. Rektor Universitas Diponegoro, Prof. Sudharto P. Hadi Mencanangkan Gerakan Penghijauan Kampus, https:/ft.undip.ac.id/rektor-universitas- 
diponegoro-prof-sudharto-p-hadi-mencanangkan-gerakan-penghijauan-kampus/ 2011, Accessed June 16, 2020

26. Kompas.Com. "Undip Wajibkan Mahasiswa Baru Tanam Pohon", https://regional.kompas.com/read/2012/08/27/17274765/undip.wajibkan.mahasisw a.baru.tanam.pohon 2012. Accessed June 16, 2020

27. Berita Tembalang. "Komitmen UNDIP Terhadap Penghijauan", http://beritatembalang.blogspot.com/2015/12/komitmen-undip-terhadappenghijauan.html, 2015. Accessed June 16, 2020

28. Manunggal. "Konsep Green Habit, Memperkenalkan Maba Undip akan Perlunya Penghijauan" https://manunggal.undip.ac.id/konsep-green-habit-memperkenalkanmaba-undip-akan-perlunya-penghijauan/. 2018 Accessed June 16, 2020

29. Tempo.co, "Universitas Diponegoro Bangun Waduk Pendidikan", https://nasional.tempo.co/read/464810/universitas-diponegoro-bangun-wadukpendidikan, 2013. Accessed June 16, 2020

30. Krjogja.com,'Pengelolaan Waduk Pendidikan Undip Dukung Greenmetric. https://www.krjogja.com/pendidikan/kampus/pengelolaan-waduk-pendidikanundip-dukung-greenmetric/, 2018. Accessed June 14, 2020

31. M. Arief Budihardjo, Wiharyanto Oktiawan, Bayu Sapto Ajie, Perencanaan Bangunan Pengolahan Air Minum Kampus Universitas Diponegoro Tembalang. https://www.academia.edu/17986870/239177630-JURNAL-PBPAM-UNDIP, Accessed June 16, 2020

32. Nasruddin dan Anita Ratnasari R. "Perbandingan Biaya Umum Transportasi Angkutan Umum dan Sepeda Motor Sebagai Moda Transportasi Oleh Mahasiswa (Studi Kasus: Kampus Universitas Diponegoro Semarang)", J. Teknik PWK 3 no. 3, 2014.

33. Republica.co.id. "Feeder Kampus Undip Direncanakan Diperpanjang Hingga Unnes".https://www.republika.co.id/berita/nasional/jabodetabeknasional/16/04/05/regional/jabodetabek/11/09/27/pendidikan/duniakampus/15/10/07/nvuq2u368-feeder-kampus-undip-direncanakan-diperpanjanghingga-unnes, 2015. Accessed June 16, 2020

34. Csr-news, Pertamina Dukung Hutan Lindung Undip, https://www.pertamina.com/en/viewarchive/csr-news/pertamina-dukung-hutanlindung-undip, 2015. Accessed June 15, 2020

35. Kompas.com,’Undip Siap Bangun Fasilitas Pengolahan Sampah Terpadu”, https://edukasi.kompas.com/read/2013/01/23/21120173/Undip.Siap.Bangun.Fasilit as.Pengolahan.Sampah.Terpadu, 2013. Accessed June 15, 2020

36. Syafrudin, "Pengelolaan Sampah Universitas Diponegoro" (2019)

37. Universitas Diponegoro, Prospektur Undip 2010 : Meniti Jalan Menuju Universitas Kelas Dunia (2010)

38. Peraturan Rektor Universitas Diponegoro Nomor 22 Tahun 2017 tentang Rencana Strategis Universitas Diponegoro 2015 - 2019 Revisi

39. Kurniawan Akbar, Yanuar Luqman, Djoko Setiabudi, Komunikasi Strategis Universitas Diponegoro dan Universitas Negeri Semarang Dalam Membangun Brand Image Universitas Sebagai Green University, Interaksi Online 1, no. 3, Agustus 2013

40. George C. Edward III, Implementing Public Policy (1980) 